\title{
Deconstruction of Ethical Predicament in J. M. Coetzee's Waiting for the Barbarians
}

\author{
HUANG HUI
}

\begin{abstract}
Waiting for the Barbarians is an allegorical novel by J. M. Coetzee, which tells a story of the confrontation of civilization and barbarism. The old Magistrate, as the main character of the novel is called, is a defender of the civilization of the Empire at the very beginning. He falls into the dilemma of the binary opposition between civilization and barbarism through the cruel torture of the Empire and the contact with the barbarians; he breaks completely with the civilization of the Empire, and achieves the salvation of his soul ultimately, after witnessing the torture of the Empire by himself. This paper, with the approaches of Ethical Literary Criticism, throws light on the construction of ethical discourse and metaphor in the novel, and analyzes how the old Magistrate falls into the ethical predicament and comes out of it through ethical choices, thus deconstructing the old Magistrate's psychological cognitive process of civilization and barbarism, and revealing the ethical callings and moral reflections of this work in relation to realistic social problems.
\end{abstract}

Keywords: J. M. Coetzee; Waiting for the Barbarians; ethical metaphor; ethical predicament

Waiting for the Barbarians, the novel that established J. M. Coetzee's worldwide reputation, is mostly traditional in style. To make a relatively objective analysis of the novel, we need to interpret the ethical predicament and ethical choice of the main character from the perspective of ethical literary criticism, and then reveal the ethical teachings manifest in the work.

\section{The Ethical Metaphor and the Development of the Ethical Line}

Coetzee's novels have not only profound meaning, they demonstrate also the author's superb grasp of narrative techniques, and the most striking feature in them is the well-chosen ethical metaphor. In Waiting for the Barbarians, being an allegorical novel, the text itself is a metaphor, and a large number of metaphors are employed in plot interpretation, characterization and the development of an ethical line. Through the interpretation of the ethical metaphors in the novel, 
we can deepen our understanding of the ethical line, thus articulating further the hidden ethical implications in the work.

In Nie Zhenzhao's words, the "ethical line is the linear structure of literary text...the role of it is to put together the ethical knots, forming the intricate ethical structure. In the ethical structure of the literary text, the manifestation of the ethical line is the dominant ethical issue that runs through the whole literary work." (Nie 2014: 265) The old Magistrate is in a complex network of ethical relationships from beginning to end, including his relationship with the Empire and the barbarian girl. Along with the change of the old Magistrate's ethical identity, the main and secondary ethical lines are formed in Waiting for the Barbarians. The main ethical line is "waiting for the coming of the Barbarians".

The word "waiting" expresses a complex mentality of expectation and uneasiness, excitement and longing: on the one hand, white men, represented by the author, know well about the unfair treatment and injustice suffered by the "Barbarians" in African history, and realize that the rising of the black Africa is the inevitable result of the end of the declining colonial era. As a progressive intellectual with a conscience, J. M. Coetzee approves the inevitability of the historical development and expects the coming of the Barbarians; on the other hand, in view of the fact that "the Barbarians" in history have suffered at the hands of the white colonists, they cannot predict the outcome of the coming of the Barbarians, considering the unreliability of human nature.

The secondary ethical line of the novel is the barbarian girl in the old Magistrate's dreams. All in all there are twelve dreams in the work, in the first one the old Magistrate sees the figure of a woman and in the last he touches the corpse of the parrot in the tomb. The most important ethical metaphor in these dreams is the barbarian girl, who symbolizes the object - the barbarians the empire is going to exterminate. These short and obscure dreams have rich symbolic significance, which reveal many details of the old Magistrate's changing psychological state. With the development of the dreams, the old Magistrate witnesses the torture and slaughter "the Barbarians" have gone through, and he gradually realizes the hypocrisy and cruelty of "the Civilized" acting on behalf of the Empire. These dreams witness his final embarkation on a difficult road to self-redemption.

Like other figures in Coetzee's work, the old Magistrate, at the beginning of the war against the barbarians, is a morally indifferent nobody. He obeys the will of the empire, defends its interests, and has no doubts on the "civilization" of the Empire. But during the battle against the barbarians, he realizes the cruelty and baseness of the Empire. Then his conscience starts to awaken. He begins to reflect on the "civilization" of the empire and question its legitimacy, especially after experiencing the torture of the empire himself. He breaks completely 
HUANG

with false civilization and achieves the redemption of his soul. During this complicated spiritual experience, the image of the barbarian girl in his dreams is increasingly clear. In fact, the author regards the increasingly clear image of the girl as the feedback on the awakening of the old Magistrate's conscience. The overlap of the end of the story and the dreams shows the originality of the novel. In the last chapter, when the old Magistrate walks through the square in real life, he does not see the barbarian girl in the snow, but sees children in real life making a snowman, "This is not the scene I dreamed of. Like much else nowadays I leave it feeling stupid, like a man who lost his way long ago but presses on along a road that may lead nowhere." (WB 207) At this moment, the main and secondary ethical line perfectly overlap.

\section{Binary Opposition and the Formation of Ethical Knots}

The ethical knots on the main and secondary ethical lines form a complex ethical structure of the work. In Nie Zhenzhao's words, "the ethical knot is the centralized reflection of the contradictions and conflicts in the structure of literary works. The ethical knots form the ethical predicament, revealing the basic ethical questions of literary texts." (Nie 2014: 258)

Many ethical metaphors in the novel that are the prerequisite to the formation and development of ethical knots, reveal the old Magistrate's ethical predicament and predict his ethical choice. The quantity of ethical knots and the difficulty of its deconstruction determine the complexity level of the text. With the approaches of Ethical Literary Criticism, we can interpret the text as explaining "the formation process of ethical knots on the ethical line." (Nie 2014: 259)

The most important ethical knot in the novel is the binary opposition between civilization and barbarism, which derives from the binary opposition between the "Self" and the "Other". The empire naturally thinks of itself as civilized and represents morally advanced civilization. Another cultural group is classified as "the barbarians" by the empire and thought to be representatives of evil and backwardness. By means of the class division, the empire settled its status in order to colonize and drive the barbarians out. Coetzee is skeptical of the binary opposition between civilization and barbarism in the Waiting for the Barbarians. The word "barbarian" can be traced to its Latin root "barbarus" or Greek root "barbaros", meaning "foreign" that does not contain a derogatory sense in itself. "Barbarian refers to those who have different languages and customs from the speaker.” (Baral 2008: 63) The old Magistrate 
finds that the knowledge of the empire concerning the barbarians "is founded on nothing more substantial than differences" (WB 70)

The difference between the barbarians and the people of the empire is that they are nomads rather than farmers, and that they use bones and wood instead of metal to make tools, and that they wear clothes made of wool and animal skins rather than cotton, and that they live on meat and milk instead of cereals and vegetables, and that they live in tents rather than houses. These are nothing more than differences in living habits, customs and other aspects of people, while they serve as the source of prejudice and discrimination for the civilized against the barbarians. To us, that discrimination without moral foundation is the main reason for the formation of the binary opposition between civilization and barbarism. Therefore, "waiting for the coming of the barbarians", the main ethical line, will lead to great changes of the old Magistrate's ethical identity and a serious identity crisis which will result in various contradictions, thus forming the ethical knots.

In fact, the civilized imposed the binary opposition between civilization and barbarism on the Barbarians. "These river people are aboriginal, older even than the nomads. They live in settlements of two or three families along the banks of the river. They live in fear of everyone, always skulking in the reeds; what can they possibly know of a great barbarian enterprise against the Empire?" (WB 26) These river people have no hostile sentiments towards the Empire, but they are called "the barbarians" and "enemy" by the empire. It is clear that their real identity is extremely inconsistent with the character imposed by the Empire. In contrast, the people of the empire gradually undermine the values of civilized people. Particularly at the end of the novel, the guardians of civilization in the empire are not different from the destroyers of civilization, and the so-called values of civilization are not maintained at all in the expulsion and punishment of the barbarians. What Coetzee really tries to say is that the "barbarians" are merely a distorted symbol of the "marginalized people" imposed on them by the "civilized people" who are dominant and have the power to speak. Their position might be reversed in different historical stages.

In addition, there are many other ethical knots on the main ethical line: the white male as a subject of desire; the "Other" female as an object of desire; the law of the jungle, etc. For example, Coetzee mostly uses "gaze mechanisms" in his novels to establish the position of subject and object. The firstperson narrative empowers imperial officials to gaze at the female body from the confluence of the racial and gender rights of white males. In order to figure out the reasons for the scars on the barbarian girl's body, the old Magistrate gives her a strange washing ceremony every evening. The process of gazing at and exploring the girl's body implies his absolute male right and a strong 
desire of conquest. The barbarian girl under the old Magistrate's gaze is not completely subordinate to the power of the white male. To the contrary, she uses her own gaze to challenge male hegemony. The old Magistrate becomes restless under the girl's gaze and has to find other women to vent his desire. With the construction and deconstruction of these ethical knots, the plot develops and reaches the climax, thus further revealing the diversity and complexity of the old Magistrate's ethical identity.

\section{The Protagonist's Ethical Predicament and Ethical Choice}

"Ethical predicament means vexed contradiction caused by ethical confusion in the literary text." (Nie 2014: 258) The first ethical predicament faced by the old Magistrate is witnessing the torture of the barbarians imposed on them by the civilized people of the empire. The old Magistrate first tries to deny what is happening in the torture chamber by stopping his ears. However, the screaming of the tortured barbarians intrudes upon his consciousness and provokes a sense of guilt in him. After witnessing Colonel Joll implanting the marks of torture upon the barbarians to assure their identity as enemies, his sense of guilt grows. After witnessing Joll's torturing of the barbarians, "my ear is even tuned to the pitch of human pain" (WB 9). It is the first time that the old Magistrate faces an ethical predicament: closing his eyes to the violence of the empire will be against his conscience; ending the violence means resistance to Colonel Joll and the civilization of the empire. The old Magistrate takes some remedial measures out of sympathy and compassion, but he had never doubted the civilization of the empire, "Then, all together, we lose sympathy with them." (WB 28) "I curse Colonel Joll for all the trouble he has brought me, and for the shame too." (WB 29) At the moment, he still stands on the position of the civilized. He tries to offer an explanation for the empire in his subconscious.

The old Magistrate's compassion, however, is of little use, because Colonel Joll, on behalf of the Third Bureau goes on showing tremendous ferocity to the barbarians. In order to realize self-salvation, he takes in the barbarian girl and looks after her carefully. Though the girl keeps silent, the scars all over her body reveal the sin of the empire and the absurdity of the civilized world, and her blind eyes cast a shadow in his mind. He starts to pay close attention to her experience in the chamber, and inquires her constantly about the torture, even asks the soldiers for further details. The old Magistrate always uses the empire's language to communicate with the girl and never tries to learn the girl's language, so he cannot rescue and cure the girl, and his self-redemption is eventually in vain. 
Right before the empire attacks the barbarians, the old Magistrate undergoes the second ethical predicament: keeping the girl with him or bringing the girl back to her place. He is faced with two difficult ethical choices, and each has s strong ethical orientation. It turns out that the old Magistrate, whose name is not even mentioned, chooses the latter one: to save the girl's life at the expense of himself. This event changes the characters' ethical identity and their ethical relationship, and even causes ethical confusion to some extent. Escorting the girl home, the old Magistrate overhears the vivid interaction between the "silent" girl and the soldiers. Only then does he find that "she is a witty, attractive young woman!" (WB 86) He begins to regret that he has not found a way to communicate with that girl. The old Magistrate's ethical identity has undergone fundamental changes after returning from the journey: from the imperial officer to the traitor of the empire, from the defender to the rebel against the imperial civilization. The old Magistrate's ethical relationship with the empire has also changed: from the master to the prisoner, from the civilized to the barbarian under the torture of the empire. It is the important moment when the old Magistrate escorts the girl back to her hometown that prompts the old Magistrate to lean toward the barbarians on the balance of civilization and barbarism.

After sneaking out of the prison, the old Magistrate sees the soldiers of the empire tormenting the prisoners in the square and falls into the third ethical predicament. "I ought to go back to my cell. As a gesture it will have no effect, it will not even be noticed. Nevertheless, for my own sake, as a gesture to myself alone, I ought to return to the cool dark and lock the door and bend the key and stop my ears to the noise of patriotic bloodlust and close my lips and never speak again." (WB 140) Then he sees Colonel Joll torturing the barbarian prisoners. After beating the barbarian with his baton, Colonel Joll is holding a four-pound hammer, which is mostly used to knock in tent-pegs. The old Magistrate finally cannot put up with it any longer and is determined to burst out everything. Although sentenced to prison, he is still hopeful and expects to be set free according to the law of the empire, thus he becomes civilized again while he stays in prison and behaves well. His conscience is still vacillating between civilization and barbarism but now he is fed up with the brutality of the empire. Out of his conscience, out of justice, he cries out openly against the civilization of the empire. That is when he completely abandons his ethical identity as the civilized of the empire and joins the barbarians. He comes out of the predicament of the binary opposition between civilization and barbarism by ridding himself of the hypocrisy of the so-called civilization, and has a clear conscience finally. "I need not have been anxious after all!" (WB 181) 
HUANG

The novel presents the old Magistrate's ethical predicament under different ethical circumstances, and his ethical choice between civilization and barbarism that form a binary opposition. At the beginning, the old Magistrate is partial to civilization. He resolutely safeguards the civilization of Empire and disregards the barbarians. After sheltering the barbarian girl and escorting her back to her hometown, he realizes the hypocrisy of the Empire, which prompts him to reflect on civilization and barbarism. As the old Magistrate knows more and goes deeper, he gradually slides from civilization to barbarism, and finally breaks completely with the civilization of Empire after witnessing Colonel Joll and others torture the barbarians. He gains peace in his heart and achieves ethical redemption despite all the torture he suffers after siding with the barbarians.

J. M. Coetzee "is a scrupulous doubter, ruthless in his criticism of the cruel rationalism and cosmetic morality of western civilization." (PR) In this novel, Coetzee guides us to speculate on the chronic diseases of civilization by showing us the old Magistrate's ethical predicament and ethical choices he made. Coetzee has negative attitudes towards the binary opposition between civilization and barbarism, which is just the cultural difference of different races. The end of the novel implies the collapse of the imperial power and expresses Coetzee's great vision of human dignity and human peace.

Waiting for the Barbarians has rich ethical connotations in it. With the construction and deconstruction of the ethical knots, the old Magistrate's emotional world and the mental life of the white intellectuals represented by him is shown. It calls on the white intellectuals to actively seek and establish their ethical identity to get out of the constraints of the social ethical environment, thus achieving their legitimate and reasonable ethical appeal. Nie Zhenzhao states that "the ethical value of literature lies in its ethical teaching." (Nie 2014: 7) Literature is a way to express the author's ethical thoughts, which achieves its ethical teaching function through the artistic reproduction of real life. We can obtain the enlightenment of real life after interpreting it with the approaches of Ethical Literary Criticism.

\author{
Huang Hui \\ huanghui@188.com \\ College of Chinese Language and literature \\ 152 Luoyu Road, Wuhan City, 430079, \\ Hubei Province \\ P.R. CHINA
}


Deconstruction of Ethical Predicament in J. M. Coetzee's Waiting for the Barbarians

\section{Works Cited}

Baral, Kailash C. 2008. J. M. Coetzee: Critical Perspectives. New Delhi: Pencraft International.

Nie Zhenzhao. 2014. Introduction to Ethical Literary Criticism. Beijing: Peking UP.

$P R=$ Press Release. 2003. Laureates. http://www.nobelprize.org/nobel_prizes/ literature/laureates/2003/ press. html (6.12.2016).

WB = Coetzee, J. M. 1999 [1980]. Waiting for the Barbarians. London: Penguin. 